\title{
THE IMPACT OF DEFERRED TAX EXPENSE AND TAX PLANNING TOWARD EARNINGS MANAGEMENT AND PROFITABILITY
}

\author{
ROCKY ALFIAN BUNACA \\ NURDAYADI \\ Swiss German University, The Prominence Tower Alam Sutera, Jl. Jalur Sutera Barat Kav 15, Alam Sutera, Kota \\ Tangerang, Banten, Indonesia \\ nurdayadi@sgu.ac.id
}

\begin{abstract}
The aim of this research is to analyze the impact of Deferred Tax Expense and Tax Planning toward Earnings Management and Company's Profitability. The sample of this research are taken from 24 companies from Consumer Goods Sector that listed in Indonesia Stock Exchange from 2013 - 2017. The variables of this research are Deferred Tax Expense and Tax Planning as Independent Variables, Earnings Management as Intervening Variable, and Company's Profitability as Dependent Variable. This research use Path Regression Analysis to analyze the role of Intervening Variables in influence other variables. The result of this research, it is found that Deferred Tax Expense has a significant influence toward Earnings Management, but has no influence toward Company's Profitability. Tax Planning has no significant influence to Earnings Management, but has a significant influence toward Company's Profitability. It also found that Earnings Management as intervening variable strengthen the influence from Deferred Tax Expense toward Company's Profitability, but weaken the influence from Tax Planning toward company's profitability.
\end{abstract}

Keywords: Deferred tax expense, tax planning, earnings management, profitability

\begin{abstract}
Abstrak: Tujuan penelitian adalah untuk menganalisa pengaruh beban pajak tangguhan dan perencanaan pajak terhadap manajemen laba dan profit perusahaan. Sampel pada penelitian ini 24 perusahaan sektor barang konsumsi yang terdaftar di Bursa Efek Indonesia dari tahun 2013 sampai 2017. Variabel yang digunakan dalam penelitian ini adalah beban pajak tangguhan dan perencanaan pajak sebagai variabel independen, manajemen laba sebagai variabel intervening dan profit perusahaan sebagai variabel dependen. Penelitian ini menggunakan path regression analysis untuk menganalisa peran variabel intervening dalam mempengaruhi variabel lainnya. Hasil dari penelitian ini adalah beban pajak tangguhan berpengaruh secara signifikan terhadap manajemen laba, namun tidak berpengaruh dalam profit perusahaan. Perencanaan pajak tidak berpengaruh terhadap manajemen laba namun berpengaruh secara signifikan terhadap profit perusahan. Manajemen laba sebagai variabel intervening memperkuat pengaruh beban pajak tangguhan terhadap profit perusahaan tapi melemahkan pengaruh perencanaan pajak terhadap profit perusahaan.
\end{abstract}

Kata kunci: Beban pajak tangguhan, perencanaan pajak, manajemen laba, profitabilitas 


\section{INTRODUCTION}

A company's performance appraisal simply can be mirrored from the profit achievement of the company. The related parties in one company use the earnings information in determining the decision to be taken for the continuity of the company's operations. The profit information of a company is used by the internal and external parties of the company as a basis in making various decisions related to bonus, compensation, performance benchmarks and performance of the management as well as the basis for determining the amount of tax (Negara and Suputra 2017). Therefore, the quality of the profit information that is presented by the company certainly attracts the attention of various circles such as investors, creditors, accounting policy makers, and the government which in this case is the Directorate General of Taxation.

According to Setyawan and Harnovinsah (2016), company's profit is still heavily accounted as important information for investors and creditors as well as corporate owners. Investors, creditors and corporate owners usually use earning information to measure risk in investment and credit (Setyawan and Harnovinsah 2016). On the other hand, company's profit is manipulation targets for management to maximize their satisfaction. By choosing a specific accounting policy, the management as executor and hold responsible for operational of the company can raise and lower the company's profit in accordance with his wishes (Setyawan and Harnovinsah 2016).

Companies are now facing a very tight competition to survive in the global market. The company is now required to have various competitive advantages in order to be able to compete with other companies, not only from quantity and quality of products and services offered but also includes good financial management which means various policies in financial management must be able to guarantee the sustainability of the company's business and it is indicated by the magnitude profit achieved by a company. This is the situation that usually encourages managers to engage in deviant behaviour in presenting and reporting the earnings information known as earnings management.

Earning management is an attempt to change, hide, and manipulate the figures in the financial statements and to play out the accounting methods and procedures used by the firms (Sulistyanto 2008). Meanwhile, according to Makar, Alam, and Pearson (2000) defines earnings management as a deliberate mistake or omission in making financial statements regarding material facts and accounting data, so it will create a misleading when all information is used to make opinion or decision (Makar, Alam and Pearson 2000). Earnings management can be done through the practice of income smoothing, taking a bath, and income maximization (Scoot 2003). The concept of earnings management can be explained by using the agency theory approach. This theory explained that the practice of earnings management is influenced by the conflict of interest between the stakeholders (principal) and the management (agent) as the party that runs the interest. This conflict arises when each party seeks to achieve the desired level of prosperity.

The global financial scandal by a corporation started in 2001 in the United States by Enron Corporation, WorldCom, Global Crossing Ltd, Adelphia Communications and Xerox Corporation and other corporations is evidence of fraud committed through earnings management. Irianto (2003) explained explain that there are causes of triggering the occurrence of bankruptcies of these companies such as manipulation of bookkeeping, tax evasion, securities fraud and insider trading. The 
phenomenon of financial scandal also occurred in Indonesia. The first case was in 2001, that PT Kimia Farma Tbk marked up its net profit for 32.6 billion in 2001. At that time, Hans Tuanakota \& Mustofa Public Accounting Firm reported a net profit of 132 billion rupiah, then after a re-audit on October 3, 2002 at the request of the Ministry of SOEs and Bapepam (Indonesia Financial Service Authority), the net profit was only 99.56 billion rupiah. The second case is on the financial statements of PT Bank Lippo Tbk as of September 30, 2002 which are presented with double-entry, whereby there are differences in financial statements submitted to the public through newspapers with those reported to the Indonesia Stock Exchange. Taxation scandal also occurred in 2007, in which PT Kaltim Prima Coal (KPC) did sales manipulation to minimize taxes. After an investigation by the Directorate General of Taxation, KPC found underpayments of tax amounting to Rp 1.5 trillion. Doing sales manipulation is one of the practice of earnings management using deferred tax.

Scott (2012) explain that one of the motivations of the company to do earnings management is the tax motivation. Company will do earnings management by lowering their profits so that company can pay taxes with a smaller amount (Scott 2012). The results of research that conducted by Harmana and Suardana (2014) that the deferred tax has a positive relationship and significant effect on the company's performance, it means that when the company is able to do a good management in deferred tax, it can help company to improve the their performance (Harmana and Suardana 2014). The results of research that conducted by Philips, Pincus and Rego (2003) indicating that the deferred tax expense and accruals can detect earnings management in order to avoid loss and decrease in profit (Phillips, Pincus and Rego 2003). While Yulianti (2005) who did research about the companies that listed on the Indonesia Stock Exchange, shows that the deferred tax expense and accruals can detect earnings management activity by the company in order to avoid losses (Yulianti 2005).

Another factor that could affect earnings management is tax planning. Suandy (2008) defines tax planning as the company's efforts to minimize its tax payment as long as it is still acceptable in the applicable tax rules (Suandy 2008). Research conducted by Marques, Rodrigues, and Craig (2011) show that the efforts to minimize corporate tax payments are determined by tax planning. Firms with higher rates of income tax were found to reduce earnings to near zero. Firms with higher average income tax rates were more likely to manipulate their earnings than other firms (Marques, Rodrigues and Craig 2011). Sumomba and Hutomo (2012) did research about the effect of tax planning on earnings management, where the result there is a significant influence between tax planning with profit management (Sumomba and Hutomo 2012).

The phenomenon of earnings management has been widely used as objects in various studies, such as Scott (2012), Harmana and Suardana (2014), Philips, Pincus and Rego (2003), Yulianti (2005), Setyawan and Hernovinsah (2016), Marques, Rodrigues, and Craig (2011), Sumomba and Hutomo (2012). According to Indonesian Directorate General of Tax, 80 to 85 percent of Indonesian government income is coming from tax, it means that tax is the biggest contribution to the government income. It will lead to the strict supervision by the government regarding to tax collection (Sumomba and Hutomo 2012). According to Yulianti (2005), management is usually given the freedom to determine the own accounting policy based on accounting standard, but they still need to pay attention to the applicable tax law and regulation, it means that they can use deferred tax expense and tax planning as earnings management tool for the profit purposes, however it must be based on applicable tax law and regulation too. Government will not hesitate to sue the 
management if they are doing earnings management without pay attention to the applicable tax law and regulation, because it will cost the government and decrease state's income (Yulianti 2005).

Thus, our purpose of study is to obtain the impact of deferred tax and tax planning on the earning management, we also analyse the effect of earnings management, tax planning and deferred tax expense on firm's profitability. This study then uses earning management as intervening variable to check the impact of deferred tax expense and tax planning on firm's profitability.

This research is expected the management of firm to pay more attention to the implementation factors in PSAK No. 46 on the recognition of deferred taxes and can utilize the efficiency of tax payments through optimal tax planning.

Resmi (2009) state that the causes of difference between commercial report and fiscal report are due to differences in accounting principles, different methods and accounting procedures, differences in income and expense recognition, as well as differences in income and expense treatment. Differences in accounting profit and fiscal profit are positively related to financial reporting incentives such as financial distress and bonuses, in which case it is possible for managers to do earnings management practices by increasing or decreasing the amount of deferred tax expense recognized in the income statements (Djamaluddin, Handayani and Rahmawati 2008).

\section{Tax Planning}

Tax planning is the minimization of Taxable Income in the current year can be interpreted as maximization of taxable income in the future. The process of minimizing Taxable Income or income tax payable in the current year can be made by identifying and utilizing the relevant tax rates in making decisions regarding activation of operations, investments and financing (Harnanto 2013). Tax planning is measured using the tax retention rate formula, which a measurement of the effectiveness of tax management on the company's current year's financial statements. The size of tax management effectiveness referred to in this study is the size of the effectiveness of tax planning. The tax retention rate formula is (Wild, Subramanyam and Halsey, 2004):

Informations:

$$
\text { TRR }_{\text {it }}=\frac{\text { Net Income }_{\text {it }}}{\text { Pretax Income }_{i t}}
$$

【TRR_it: Firm i's Tax Retention Rate in year t 『Net Income_it: Firm i's Net Income in year $t$

『Pretax Income_it: Firm i's Pretax Income or income before tax in year $t$

According to Tresnajaya and Rusdin (2004) in Hidayat (2013), essentially no single person who likes to pay taxes and the potential to withstand tax payments seems already exist in taxpayers. The taxpayer always tries to pay the smallest outstanding tax, as long as it is possible by the applicable laws and regulations. Efforts that are often done by the taxpayer for that matter is to conduct tax planning.

\section{Deferred Tax}

According to Statement of Indonesian Financial Accounting Standards (PSAK) number 46 in Waluyo (2014) "Tax expense is the total amount of current tax and deferred tax that calculated in the calculation of the accounting income in a period. Current tax is the amount of the estimated tax on a taxable income in the current tax year or period, whereas deferred tax is the amount of income tax payable for future periods as a result of temporary taxable differences." The relation between tax expense, current tax, and deferred tax can be illustrated using following formula:

\section{Tax Expense $=$ Current Tax + Deferred Tax}

Tax Expense is calculated from the Accounting Profit (based on Indonesian 
Financial Accounting Standard) that directly multiplied with applicable tax tariff. However, Current Tax is calculated from the Fiscal Profit (based on Fiscal Regulation) and multiplied with applicable tax tariff. If the amount of Tax Expense is bigger than the Current Tax, then it will generate Deferred Tax Expense. In other hand, if the amount of Tax Expense is smaller than the Current Tax, then it will generate Deferred Tax Income.

According to Waluyo (2014), deferred tax is defined as: "Deferred tax as the amount of income tax recovered in future periods as a result of temporary differences that may be deducted from the remaining losses that can be compensated. Deferred tax recognition affects net loss or net loss due to the possible recognition of deferred."

Recognition on Deferred Tax (Zain 2008) For Deferred Tax Liabilities, the recognition of Deferred Tax Liability is based on the fact that the possibility of asset recovery or settlement of liabilities resulting in future tax payments being smaller or greater. However, if there will be a higher tax payment in the future, then under financial accounting standards, it should be recognized as a liability. Deferred Tax Liability Recognition Journal:

\section{Deferred Tax Expense $\quad x x x$ Deferred Tax Liabilities $\quad$ XXx}

For Deferred Tax Assets, which can be recognized if there is a possibility of a smaller tax payment in the future, then, based on financial accounting standards, it should be recognized as an asset. In other words, the possibility of a smaller future tax payment will be recorded as deferred tax assets. Deferred Tax Asset Recognition Journal:

Deferred Tax Assets XXX Deferred Tax Income $\mathrm{xxx}$
The tax allocation method is used to account for the tax impact and how those impact should be presented in the financial statements. According to Zain (2008) states that the method to allocate taxes can be done with 3 (three) ways that are:

\section{Deferred method}

This method uses the Income Statement Approach which look for the difference between the treatment of accounting and taxation from the perspective of income statement, when a transaction is recognized in the income statement both commercially and fiscally. This approach recognizes the time difference and permanent differences. The difference amount of the Income Tax Payable (based on tax basis) and the Taxable Income (based on accounting basis) in a period should be recorded and presented in the Financial Statements as Deferred Tax. The amount of deferred tax is determined based on the tax rate applicable at the time of the transaction or items that cause the difference between the income from tax basis and income from accounting occurs. This method emphasizes the matching principle in the period of the occurrence of the difference. However, the development of the business world and accounting has been so rapid with the appearance of transactions that are not recognized in the income statement but directly recognized as part of equity. When using the income statement approach, such transactions cannot be detected, so this approach is considered less relevant.

\section{Asset-Liability method}

This method uses the Balance Sheet Approach that emphasizes the usefulness of financial statements in evaluating financial position and predicting future cash flows. The balance sheet approach considers the difference in accounting treatment and taxation from the point of view of the balance sheet, i.e. the difference between book balances by 
commercial and tax base. This approach recognizes the terms of temporary differences and non-temporary differences. In this method there is a deferred tax recognition of future tax consequences of deferred tax assets and deferred tax liabilities that must be reported on the balance sheet.

\section{Net-of-Tax method}

This method do not has deferred tax recognition. The tax consequences of temporary differences are not reported separately, otherwise treated as adjustments to the value of certain assets or liabilities and related income or expenses. Under this method, the tax expense presented in the income statement is equal to the amount of income tax payable by the annual tax return.

The accounting treatment of income tax is regulated by the Indonesian Institute of Chartered Accountants through Indonesia Financial Accounting Standard No. 46 (PSAK 46) regarding the presentation of income tax on financial statements and disclosure of relevant information. Changes in the approach adopted by the Financial Accounting Standards, especially for income tax accounting from the income statement approach or deferred method into a balance sheet approach or Asset-Liability Method, has undoubtedly increased the complexity of income tax calculation due to the recognition of deferred tax on the balance sheet.

Deferred tax expense is an expense incurred due to a temporary difference between accounting income and fiscal profit (Yulianti 2005). Based on references from research that was conducted by Philips et al. (2003), explained that the scale of deferred tax expenses was expressed as an indicator of deferred tax expenses, the formula as follows:

$$
\begin{aligned}
& D T E_{i t} \\
& =\frac{\text { Firm i's deferred tax expense in year } t}{\text { Total assets at the end of year } t-1}
\end{aligned}
$$

The application of total assets due to deferred tax expense incurred as a result of temporary differences, so the cost and income of last year, will only be recognized this year

\section{Earnings Management}

Profit information as part of the financial statements is often the manipulation target through opportunistic management actions to maximize its capability, but it can disadvantage the shareholders or investors. Opportunistic action is done by choosing a specific accounting policy, so that the company's earnings can be arranged in accordance with the wishes, management behaviour to manage the earnings in accordance with the wishes known as earnings management.

The practice of earnings management can be seen in two different perspectives as a wrong (negative) action and what management should do (positive). Earnings management is said to be negative when viewed as opportunistic behavior of management to maximize their utility in facing contract compensation, debt contract and political cost. While earnings management is called positive from efficient earnings management perspective where earnings management gives management flexibility to protect themselves and the company in anticipation of unexpected events for the benefit of the parties involved in the contract.

Generally there are 3 (three) groups of earnings management empirical model which are classified as the base of measurement used, namely, aggregate accruals, specific accruals, and distribution of earnings (Sulistyanto 2008):

The accrual-based model is a model that uses discretionary accruals as projection of earnings management. This earnings management model was developed by Healy (1985), DeAngelo (1986), Jones (1981), and Dechow, Sloan, and Sweenery (1995).

The specific accruals model is an approach that calculates accruals as proxy of 
earnings management by using certain financial statement items from certain industries as well. This model was developed by McNichols and Wilson (1988), Petroni, Beaver and Engel (1996), as well as Beaver, Correia and McNichols (2011).

The earnings distribution model. This model was done by performing statistical tests on the components of profit to detect factors that affect the movement of earnings. This model was first developed by Burgtahler and Dichev (1997).

Based on references from research that was conducted by Philips et al. (2003), explained that Scaled Earnings Changes was expressed as an indicator of Earnings Management, the formula as follows:

$$
\begin{aligned}
& \text { Scaled Earning Changes } \\
& =\frac{{\text { Net } \text { Income }_{i t}-\text { Net Income }}_{i(t-1)}}{\text { Market Value Equity }_{i(t-1)}}
\end{aligned}
$$

\section{Deferred Tax Expense and Earnings Management}

Deferred tax expense is the expense incurred due to temporary differences between accounting income (profit in the financial statements for external purposes) with fiscal profit (profit that used as the basis for calculating company's tax payable). In relation to earnings management, firms have a tendency to reduce reported earnings in order to postpone taxes. Philips, Pincus \& Rego (2003) analysed the application of deferred taxes expense in identifying earnings management to achieve three profit reporting objectives: avoiding losses, avoiding profit declines and to meet analysts' earnings forecasts, and proving that deferred tax expense could be used in detecting earnings management practice (Phillips, Pincus and Rego 2003). Yulianti (2005) uses deferred tax expense in detecting earnings management practice and found that deferred tax expense can detect earnings management to avoid losses (Yulianti 2005). Then Sumomba and Hutomo (2012) also use deferred tax expense to detect earnings management where the results also proved that deferred tax expense can detect earnings management (Sumomba and Hutomo 2012). Based on the explanation above, the first hypothesis of this research is:

$\mathrm{H1}$ : There is a significant influence between Deferred Tax Expense toward Earnings Management.

\section{Tax Planning and Earnings Management}

Tax planning can be explained as an effort by management in minimizing tax payment as long as it is still in the applicable tax rules. Firms that has a good tax planning will have a significant impact on the decline in profits through taxation obligations. According to Negara and Suputra (2017), tax planning has a positive effect on earnings management, which means that the higher the tax planning, the greater the chances of companies through earnings management (Negara and Suputra 2017). Sumomba and Hutomo (2012) who also examine whether tax planning has an effect on earnings management found that tax planning has an significant influence toward earnings management (Sumomba and Hutomo 2012). Based on the above explanation, the second hypothesis to be tested in this study is:

$\mathrm{H} 2$ : There is a significant influence between Tax Planning toward Earnings Management.

\section{Deferred Tax Expense and Company's Profitability \\ According to Penman (2001),} company's profitability contains predictive value elements that can be used by users of financial statements to evaluate past, present and future events (Penman 2001). According to research that conducted by Phillips et.al (2003), it was found that deferred tax expense can has a significant influence toward earnings management with negative relationship, means that the greater the amount of deferred tax 
expense, then the amount of company's profitability will decrease, it happens because deferred tax expense is used to reduce company's profitability (Phillips, Pincus and Rego 2003). It also supported by research that conducted by Wijayanti (2006) that found there is a significant influence between deferred tax expense towar company's profitability with negative relationship (Wijayanti 2006). In other hand, research that conducted by Sri Wijayanti (2016) found that there is no influence between deferred tax expense toward company's profitability and found other factors that has a significant influence toward company's profitability, such as, sales, cost and expenses, stock price, and total assets (Wijayanti 2016) and it supported by research that conducted by Djamaluddin et.al (2008) that explain there is no influence between deferred tax expense toward company's profitability (Djamaluddin, Handayani and Rahmawati 2008). Based on the explanation above, the third hypothesis of this research is:

$\mathrm{H} 3$ : There is a significant influence between Deferred Tax Expense toward Company's Profitability.

\section{Earnings Management and Company's Profitability}

Graham et.al (2005) found that $74.1 \%$ of company executives are trying to achieve profit benchmarks or a good profit, because it is able to help them to communicate the prospect of future company growth to shareholders (Graham, Harvey and Rajgopal 2005). According to research that conducted by Syanthi et.al (2013) found that earnings management has a positive significant influence toward company's profitability, that means, if there is an intense practice in earnings management, it will be followed by the increasing of company's profitability and it also supported by research that conducted by Gill et.al (2013) that found earnings managements has a positive significant influence toward company's profitability (Gill et al. 2013). Based on the discussion above, the fourth hypothesis of this research is:

$\mathrm{H} 4$ : There is a significant influence between Earnings Management toward Company's Profitability.

\section{Tax Planning and Company's Profitability}

Pohan (2013) states that one of the main objective to be achieved by tax planning are to minimize the tax payable and to maximize the profit after tax (Pohan 2013). The research conducted by Mangunsong (2002), found that there is a positive significant influence between tax planning toward company's profitability and indicated that management trying to decrease their tax payable to increase their income (Mangunsong 2002), and it is also supported by Sugeng (2011) and Assidi et.al (2016) that also found tax planning has a positive significant influence toward company's profitability that means if the amount of tax planning that proxied with tax retention rate increase. Then it will be followed by the increasing of company's profitability (Sugeng 2011; Assidi, Aliani and Ali 2016). Based on the discussion above, the fifth hypothesis of this research is:

H5: There is a significant influence between Tax Planning toward Company's Profitability

The Influence of Deferred Tax Expense on
Company's Profitability through Earnings
Management as Intervening Variable influence has connection with the first hypothesis that explain there is a significant influence between Deferred Tax Expense toward Earnings Management and the third hypothesis that explain there is a significant influence between Deferred Tax Expense toward Company's Profitability. It can be concluded that Earnings Management as intervening variable will strengthen the influence between Deferred Tax Expense toward Company's Profitability. According to Irreza and Yulinati (2012), deferred tax expense is one of 
component in earnings management practice that management use in accordance to improving company's profitability (Irreza and Yulianti 2012). Based on the discussion above, the sixth hypothesis of this research is:

H6: Deferred Tax Expense has a significant influence toward Company's Profitability with Earnings Management as intervening variable.

\section{The Influence of Tax Planning on Company's Profitability through Earnings Management as Intervening Variable}

Based on discussion above, this influence has connection with the second hypothesis that explain there is a significant influence between Tax Planning toward Earnings Management and the fifth hypothesis that explain there is a significant influence between Tax Planning toward Company's Profitability. It can be concluded that Earnings Management as intervening variable will strengthen the influence between Tax Planning toward Company's Profitability. According to Sumomba and Hutomo (2012) that explain management tend to do tax planning by decreasing company's tax payable in accordance to earnings management practice to increase company's profitability (Sumomba and Hutomo 2012). Based on the discussion above, the sixth hypothesis of this research is:

H7: Tax Planning has a significant influence toward Company's Profitability with Earnings Management as intervening variable

\section{RESEARCH METHODS}

The object study is firms of consumer goods sector that listed on the Indonesia Stock Exchange in 2013-2017. Variables of study in this research are Tax Planning, Deferred Tax Expense, Earnings Management, and Company's Profitability.

The deferred tax expense according to Scott in Yulianti (2005) is an expense that arising from temporary differences between accounting profit (earnings in financial statements for external purposes) with fiscal profit (profit used as tax calculation) (Yulianti 2005).

The indicator that used for this variable is reference from a research that conducted by Philips, et.al (2003). The formula of deferred tax expenses is as follows:

$$
D T E_{i t}=\frac{\text { Firm } i^{\prime} \text { s deferred tax expense in year } t}{\text { Total assets at the end of year } t-1}
$$

Informations:

【DTE_it: The ratio of Deferred Tax Expense of firm $i$ in year $t$

Tax planning is measured using the tax retention rate formula, which to analyses the effectiveness of tax management on the company's current year's financial statements (Wild et al. 2004). The size of tax management effectiveness referred to in this study is the size of the effectiveness of tax planning. The tax retention rate formula is (Wild, Subramanyam and Halsey, 2004)

Informations:

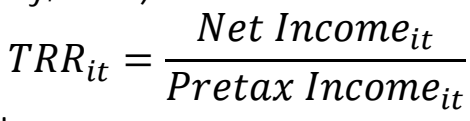

【TRR_it: Firm i's Tax Retention Rate in year t 『Net Income_it: Firm i's Net Income in year $t$

『Pretax Income_it: Firm i's Pretax Income or income before tax in year $t$

Intervening variable in this research is earnings management. Earnings management is a deliberate management intervention in the process of determining profits to gain some personal gain. Based on Phillips et al. (2003), the formula for variable earnings management is measured using the earnings distribution approach:

$$
\begin{aligned}
& \text { Scaled Earning Changes } \\
& =\frac{{\text { Net } \text { Income }_{i t}}_{\text {Net Income }}(t-1)}{\text { Market Value Equity }}
\end{aligned}
$$

『Scaled Earning Changes_it: This is one of Earnings distribution approach. If the value is zero or positive, then the firm avoids earnings 
decreasing. If the value is negative, then the firm avoids reporting losses. In this study, the value is only used as additional information on descriptive statistics.

『Market Value Equity_(i(t-1)): Market Value of Equity of firm i in year t-1 (using market capitalization value). The capitalization value is measured by multiplying the number of outstanding shares of company $i$ at the end of the year t-1 with the company's stock price at the end of year $t-1$.

Dependent variable in this research is company's profitability. Profitability is one of measurement in detecting the sustainability of a company and is used as a criterion from the assessment of the results of the activities of the company. The size of company's profitability is calculated using Return on Assets (ROA): Information:

$$
R O A_{i t}=\frac{\text { Net Income }_{i t}}{\text { Total Assetsts }}
$$

『ROA_it : Firm i's Return on Assets in year $t$

The research model of this research is an abstraction of the phenomena that being studied so the research model can be described as follows:

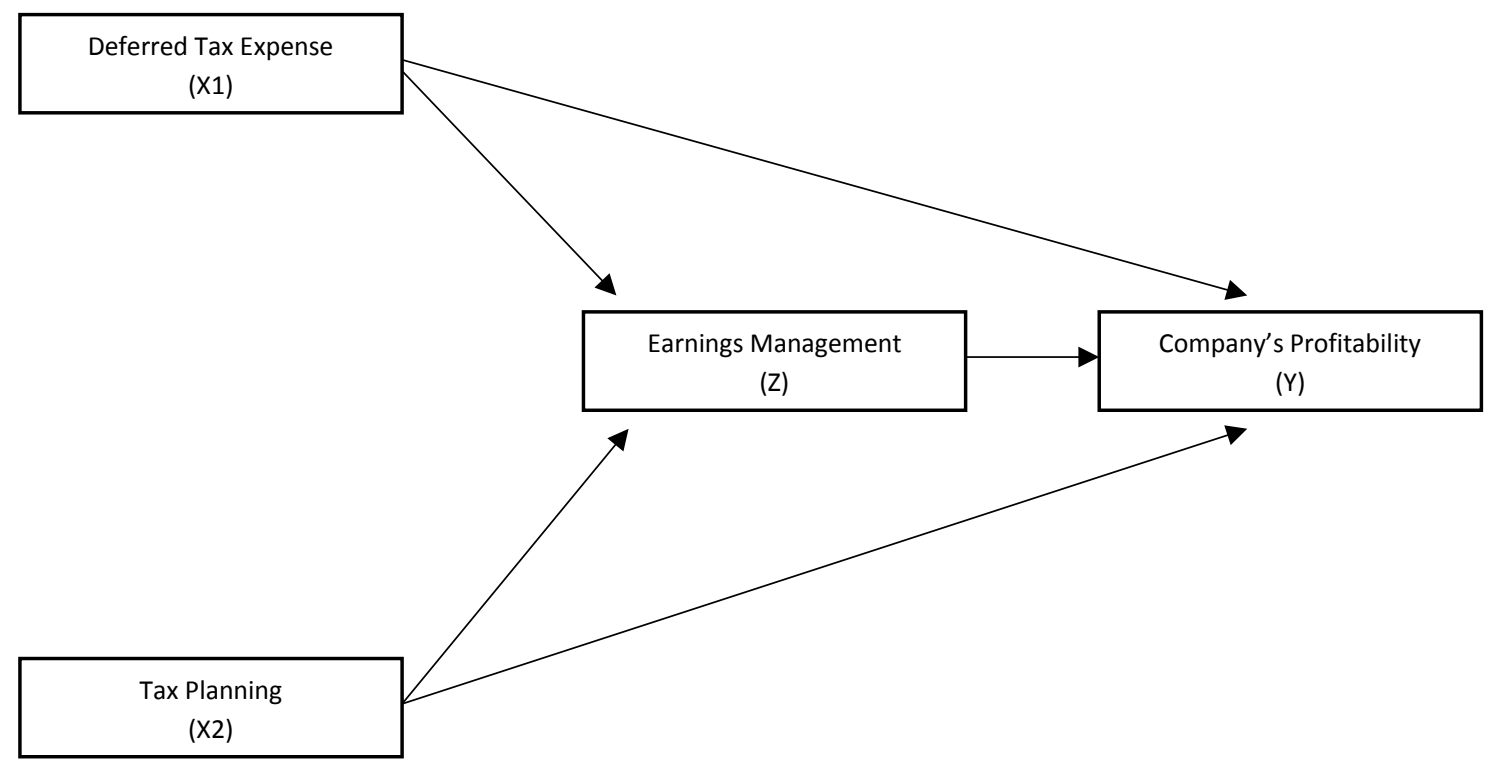

Figure 1 Research Model

\section{RESULT}

Follow descriptie statistics for each variables.

Table 1 Deferred Tax Expense Descriptive Statistic

\begin{tabular}{lccccc}
\hline & $\mathbf{2 0 1 3}$ & $\mathbf{2 0 1 4}$ & $\mathbf{2 0 1 5}$ & $\mathbf{2 0 1 6}$ & $\mathbf{2 0 1 7}$ \\
\hline Minimum & 0.00042 & 0.00014 & 0.00014 & 0.00014 & 0.00026 \\
Maximum & 0.02991 & 0.00955 & 0.01103 & 0.02600 & 0.00961 \\
Mean & 0.00461 & 0.00389 & 0.00320 & 0.00449 & 0.00332 \\
Std. Deviation & 0.00648 & 0.00312 & 0.00266 & 0.00543 & 0.00266 \\
\hline
\end{tabular}


Table 2 Tax Planning Descriptive Statistic

\begin{tabular}{lccccc}
\hline & $\mathbf{2 0 1 3}$ & $\mathbf{2 0 1 4}$ & $\mathbf{2 0 1 5}$ & $\mathbf{2 0 1 6}$ & $\mathbf{2 0 1 7}$ \\
\hline Minimum & 0.46068 & 0.57248 & 0.57728 & 0.61333 & 0.56505 \\
Maximum & 0.94023 & 0.82615 & 0.93372 & 0.90776 & 0.83925 \\
Mean & 0.73952 & 0.74296 & 0.74500 & 0.74359 & 0.73640 \\
Std. Deviation & 0.07455 & 0.05174 & 0.06200 & 0.06538 & 0.05084 \\
\hline
\end{tabular}

Table 3 Earnings Management Statistic Descriptive

\begin{tabular}{lccccc}
\hline & $\mathbf{2 0 1 3}$ & $\mathbf{2 0 1 4}$ & $\mathbf{2 0 1 5}$ & $\mathbf{2 0 1 6}$ & $\mathbf{2 0 1 7}$ \\
\hline Minimum & -0.02366 & -0.10787 & -0.05533 & -0.15215 & -0.18536 \\
Maximum & 0.13849 & 0.06569 & 0.32641 & 0.17821 & 0.16069 \\
Mean & 0.01489 & -0.00712 & 0.01814 & 0.00327 & -0.00006 \\
Std. Deviation & 0.03744 & 0.03443 & 0.07211 & 0.05639 & 0.06021 \\
\hline
\end{tabular}

Table 4 Company's Profitability Statistic Descriptive

\begin{tabular}{lccccc}
\hline & $\mathbf{2 0 1 3}$ & $\mathbf{2 0 1 4}$ & $\mathbf{2 0 1 5}$ & $\mathbf{2 0 1 6}$ & $\mathbf{2 0 1 7}$ \\
\hline Minimum & 0.00285 & 0.00216 & 0.00500 & 0.00260 & 0.00864 \\
Maximum & 0.65720 & 0.41502 & 0.37202 & 0.43170 & 0.52670 \\
Mean & 0.13905 & 0.11487 & 0.11323 & 0.11992 & 0.11420 \\
Std. Deviation & 0.14547 & 0.10892 & 0.09072 & 0.11012 & 0.12191 \\
\hline
\end{tabular}

There is decreasing trend in deferred tax expenses of company, after three consecutive year slump, this variable increases to 0.0049 in year 2016, then again decrease in 2017. The mean of Tax planning relatively stable during the period, it is around 0.73 to 0.74 . Meanwhile, earnings management variable shows flipping value, negative and positive. The las variable is profitability measured by $R O A$, it seems that the average profitability ratio constant at around 11 percent starting year 2014, after reaching the highest point in year 2013 at 13.9 percent.

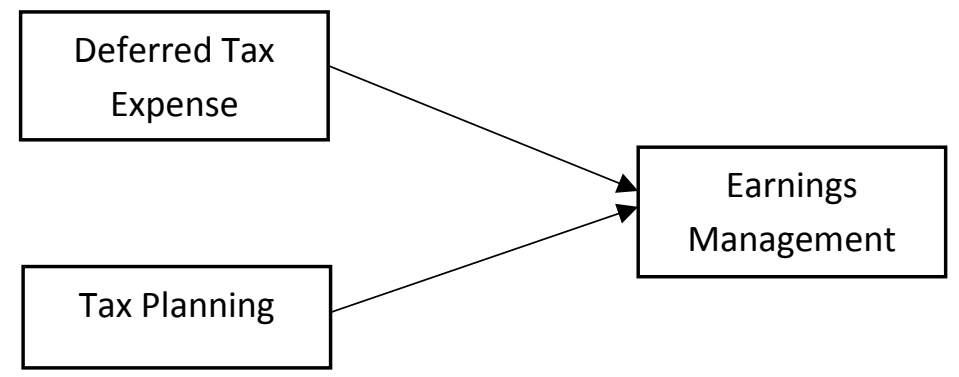

Figure 2 Substructure Model 1

The size of $\mathrm{R}$ square $\left(R^{2}\right)$ is 0.059 . This number means that deferred tax expense explaine the movement and tax planning toward earnings management simultaneously by $5.9 \%$. To find out the feasibility of the regression model is drawn the figures from the ANOVA table below. 
Table 5 ANOVA Model 1

\begin{tabular}{ccc}
\hline Model & F & Sig. \\
\hline Regression 1 & 3.639 & 0.029 \\
\hline
\end{tabular}

From the calculation, it obtained that the number of $F$-value equal to 3.539 and it is bigger than F-table that equal to 3.07 so F-value $>$ Ftable, then $\mathrm{Ho}$ is rejected and $\mathrm{Ha}$ accepted.
Thus, the regression model is feasible and correct. The conclusion is that deferred tax expense and tax planning simultaneously influence earnings management significantly.

Table 6 Partial T-Test Model 1

\begin{tabular}{lccc}
\hline \multicolumn{1}{c}{ Model } & $\begin{array}{c}\text { Unstandardized } \\
\text { Coefficients Beta }\end{array}$ & T & Sig. \\
\hline (Constant) & -2.534 & -2.944 & 0.004 \\
DTE & 0.234 & 2.009 & 0.047 \\
Tax Planning & 2.839 & 1.840 & 0.068 \\
\hline
\end{tabular}

The Influence of Deferred Tax Expense toward Earnings Management. Based on the Table 6, it obtained t-value of $2.009>$ t-table of 1.658, then $\mathrm{Ho}$ is rejected and $\mathrm{Ha}$ accepted. It means that there is an influence between deferred tax expense toward earnings management. The size of influence of deferred tax expense on earnings management are equal to 0.234 or $23.4 \%$ and it is considered significant because the significance value is $0.047<a=$ 0.05
The Influence of Tax Planning toward Earnings Management. Based on Table 6, it can be seen for the test result of the tax planning toward earnings management, it obtained the coefficient of 2.839 with $\rho$-value of 0.68 . The value of $\rho$-value is greater than a $(0.068>0.05)$ then $\mathrm{Ha}$ is rejected. Thus it can be concluded there is no significant influence of tax planning toward earnings management.

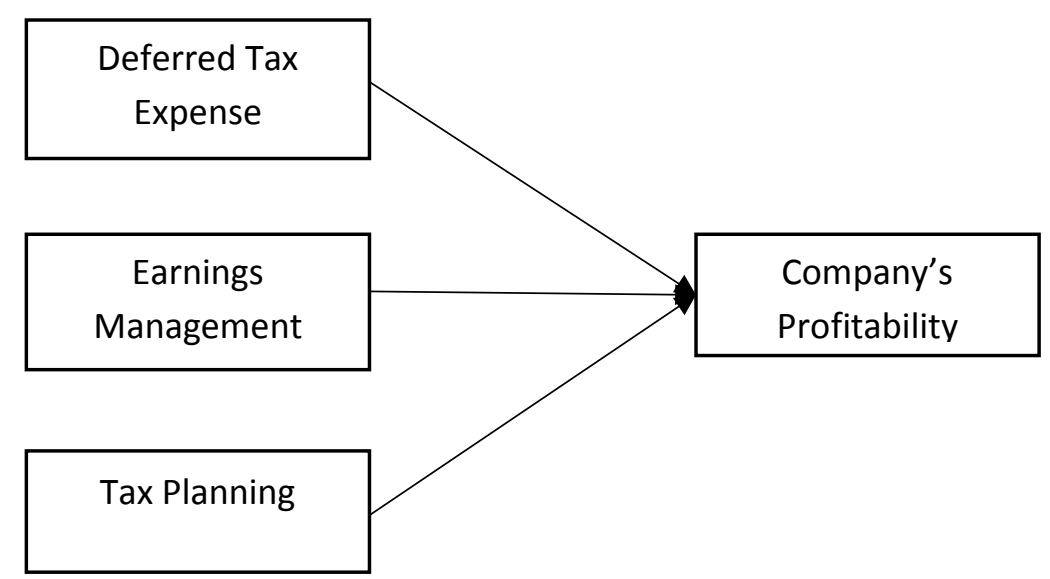

Figure 3 Substructure Model 2 
Table 7 Determination Coefficients Model 2

\begin{tabular}{c|c}
\hline Model & R Square \\
\hline 2 & 0.345 \\
\hline
\end{tabular}

The size of $R$ square $\left(R^{2}\right)$ is 0.345 . This number means that the influence of deferred tax expense, earnings management, and tax planning toward company's profitability simultaneously by $34.5 \%$. To find out the feasibility of the regression model is drawn the figures from the ANOVA table below.

Table 8 ANOVA Model 2

\begin{tabular}{c|c|c}
\hline Model & F & Sig. \\
\hline 2 & 20.325 & 0.000 \\
\hline
\end{tabular}

If F-value $>\mathrm{F}$-table, then $\mathrm{Ha}$ is accepted and if $\mathrm{F}$-value $<\mathrm{F}$-table, then $\mathrm{Ho}$ is accepted and $\mathrm{Ha}$ rejected. From the calculation, it obtained that the number of F-value equal to 20.325 and it is bigger than F-table that equal to 2.68 so $\mathrm{F}$ value > F-table, then $\mathrm{Ha}$ accepted. Thus, the regression model is feasible and correct. The conclusion is that deferred tax expense, earnings management, and tax planning simultaneously influence company's profitability. The influence is $34.5 \%$ and it is significant, because the significance value is $0.000<a=$ 0.05 . The influence of other variables outside the regression model is calculated by the formula: $(1-r 2)$ or $(1-0,345)=0.655$ or $65.5 \%$.

Table 9 Partial T-Test Model 2

\begin{tabular}{lccc}
\hline \multicolumn{1}{c}{ Model } & $\begin{array}{c}\text { Unstandardized } \\
\text { Coefficients Beta }\end{array}$ & $\mathbf{T}$ & Sig. \\
\hline (Constant) & -1.385 & -2.721 & 0.008 \\
DTE & -0.067 & -0.983 & 0.328 \\
EM & 0.107 & 2.036 & 0.044 \\
Tax Planning & 6.802 & 7.620 & 0.000 \\
\hline
\end{tabular}

If $\mathrm{t}$-value $>\mathrm{t}$-table, then $\mathrm{Ha}$ accepted and if $\mathrm{t}$-value $<\mathrm{t}$-table, then $\mathrm{Ha}$ rejected. The number of $t$-table with the condition $a=0.05$ and $\mathrm{df}=(\mathrm{n}-\mathrm{k})$ or $(120-4)=116$, from that condition, it obtained t-table equal to 1.658 .

The Influence of Deferred Tax Expense toward Company's Profitability. Based on Table 4.16 , it can be seen for the test result of the deferred tax expense toward company's profitability, it obtained the coefficient of -0.983 with $\rho$-value of 0.328 . The value of $\rho$-value is greater than a $(0.328>0.05)$ then $\mathrm{Ha}$ is rejected. Thus, it can be concluded there is no significant influence of deferred tax expense toward company's profitability.

The Influence of Earnings Management toward Company's Profitability. Based on the Table 4.16, it obtained t-value of $2.036>$ t-table of 1.658 , then $\mathrm{Ha}$ accepted. It means that there is an influence between earnings management toward company's profitability. The size of influence of deferred tax expense on earnings management are equal to 0.107 or $10.7 \%$ and it is considered significant because the significance value is $0.044<a=0.05$.

The Influence of Tax Planning towards Company's Profitability. Based on the Table 
4.16, it obtained t-value of $7.620>$ t-table of 1.658 , then $\mathrm{Ha}$ accepted. It means that there is an influence between tax planning toward company's profitability. The size of influence of deferred tax expense on earnings management are equal to 6.802 and it is considered significant because the significance value is $0.000<a=$ 0.05 .
The Influence of Deferred Tax Expense on Company's Profitability through Earnings Management as Intervening Variable.

The path coefficient calculation begins by making two structural equations, which is the regression equation that showing the hypothesis relationship (Ghozali 2011). Output result for the first regression equation (1):

Table 10 Regression Result DTE to EM

\begin{tabular}{lccc}
\hline Model & $\begin{array}{c}\text { Unstandardized } \\
\text { Coefficients Beta }\end{array}$ & $\begin{array}{c}\text { Standard } \\
\text { Error }\end{array}$ & R Square \\
\hline (Constant) & -3.419 & 0.721 & 0.031 \\
DTE & 0.230 & 0.118 & \\
\hline
\end{tabular}

Based on output above can be made the first regression equation, as follow:

\begin{tabular}{lccc}
\multicolumn{4}{c}{ Table 11 Regression Result DTE and EM to Profitability } \\
\hline Model & $\begin{array}{c}\text { Unstandardized } \\
\text { Coefficients Beta }\end{array}$ & $\begin{array}{c}\text { Standard } \\
\text { Error }\end{array}$ & R Square \\
\hline (Constant) & -3.419 & 0.542 & \\
DTE & -0.092 & 0.082 & 0.016 \\
EM & -0.040 & 0.063 & \\
\hline
\end{tabular}

Based on output above can be made the second regression equation, as follow: 


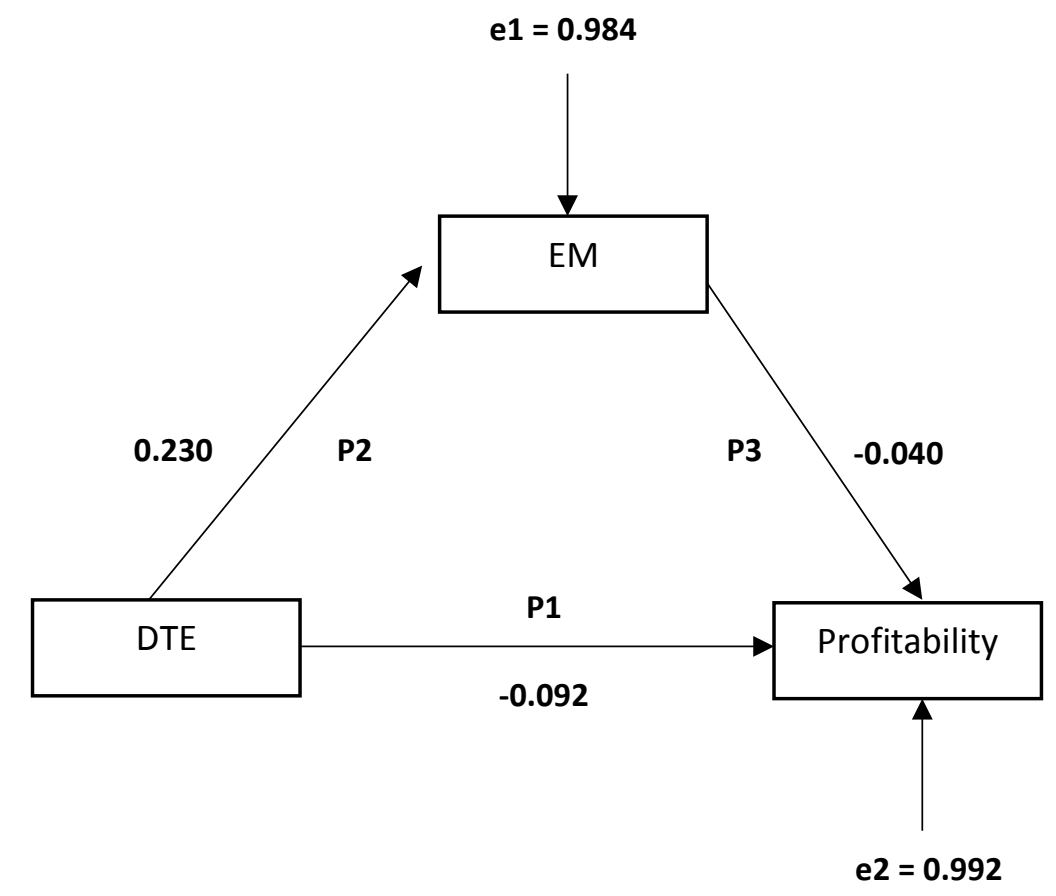

Figure 4 Path Coefficient DTE to Profitability through EM

The result of path analysis shows that deferred tax expense can influence directly to earnings management and can also indirectly influence from deferred tax expense to earnings management (as intervening) and then to

\section{Direct influence from DTE to Profitability} Indirect influence from DTE to EM to Profitability Total influence

Based on the above calculation, it can be known the influence between variables either direct influence, indirect influence and total influence. The indirect influence from DTE to Profitability through EM equal to -0.0092 is greater than the direct influence from DTE to Profitability, so that EM strengthens the influence from DTE toward Profitability. The influence of mediating variable (indirect effect) that coming from the coefficient multiplication (P2 X P3) will be tested using Sobel Test to find out, whether the indirect effect is significant or not. company's profitability. The calculation of direct influence, indirect influence and total influence of deferred tax expense toward company's profitability are as follows:

$$
\begin{array}{lll}
= & \mathrm{P} 1 & -0.092 \\
= & \mathrm{P} 2 \times \mathrm{P} 3 & -0.0092 \\
=\mathrm{P} 1+(\mathrm{P} 2 \times \mathrm{P} 3) & = & -0.1012
\end{array}
$$

Looking for standard error of indirect influence coefficient (Sp2p3) $=0.01701$. Based on the above Sp2p3 results, then it can be calculated $t$ value statistics, the $T$ test is -5.4076

Based on the above calculation, it can be concluded that with the significance level of $5 \%$, then the T-value that equal to 5.4076 is bigger than the T-Table that equal to 1.658. It can conclude that the coefficient of mediating variable has a significant influence. 
The Influence of Tax Planning towards Company's Profitability through Earnings Management as Intervening Variable.

The path coefficient calculation begins by making two structural equations, which is the regression equation that showing the hypothesis relationship. Output result for the first regression equation (1):

Table 12 Regression Result Tax Planning to EM

\begin{tabular}{lccc}
\hline \multicolumn{1}{c}{ Model } & $\begin{array}{c}\text { Unstandardized } \\
\text { Coefficients Beta }\end{array}$ & $\begin{array}{c}\text { Standard } \\
\text { Error }\end{array}$ & R Square \\
\hline (Constant) & -3.963 & 0.492 & 0.026 \\
Tax Planning & 2.777 & 1.562 & \\
\hline
\end{tabular}

Based on output above can be made the first regression equation, as follow:

Table 13 Regression Result Tax Planning to Profitability through EM

\begin{tabular}{lccc}
\hline \multicolumn{1}{c}{ Model } & $\begin{array}{c}\text { Unstandardized } \\
\text { Coefficients Beta }\end{array}$ & $\begin{array}{c}\text { Standard } \\
\text { Error }\end{array}$ & R Square \\
\hline (Constant) & -1.017 & 0.345 & \\
Tax Planning & 6.846 & 0.892 & 0.339 \\
EM & -0.117 & 0.052 & \\
\hline
\end{tabular}

The first output provides unstandardized beta value of Tax Planning in equation (1) is 2.777. Unstandardized beta coefficient value 2.777 is the path value for P2. At second output regression equation (2) unstandardized beta value for Tax Planning is 6.846 and for Earnings Management is -0.117 . The unstandardized beta value of 6.846 is the path value for $\mathrm{P} 1$ and unstandardized beta value of -0.117 is path value for $P 3$. 


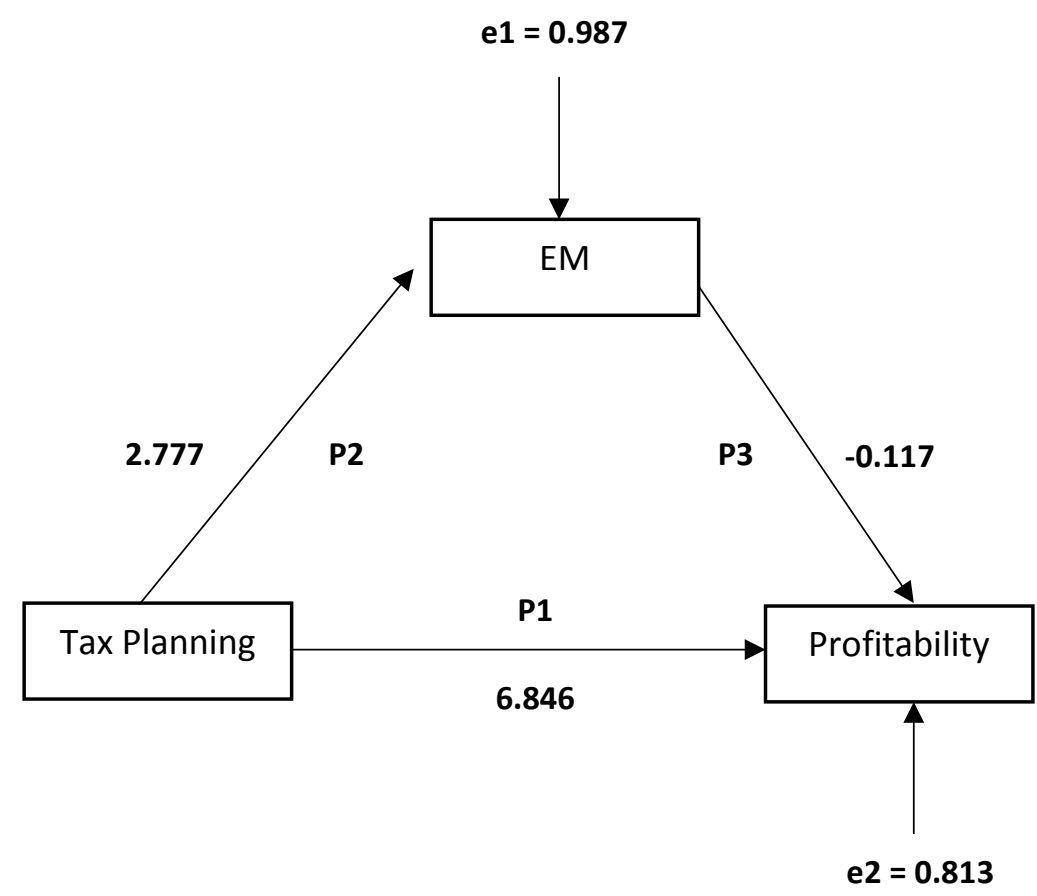

Figure 5 Path Coefficient Tax Planning to ProfitapıIIty tnrough EM

The result of path analysis shows that tax planning can influence directly to earnings management and can also indirectly influence from tax planning to earnings management (as

Direct influence from Tax Planning to Profitability Indirect influence from TaxPlanning to EM to Profitability Total influence

Based on the above calculation, it can be known the influence between variables either direct influence, indirect influence and total influence. The indirect influence from Tax Planning to Profitability through EM equal to 0.325 is lower than the direct influence from Tax Planning to Profitability that equal to 6.846 , so that EM weakens the influence from Tax Planning towards Profitability. It can be concluded that direct influence from tax planning toward company's profitability is more effective than indirect influence from tax planning to company's profitability through earnings management. The direct influence also has a intervening) and then to company's profitability. The calculation of direct influence, indirect influence and total influence of tax planning toward company's profitability are as follows:

$$
\begin{aligned}
& =\mathrm{P} 1=6.846 \\
& =\mathrm{P} 2 \times \mathrm{P} 3=-0.325 \\
& =\mathrm{P} 1+(\mathrm{P} 2 \times \mathrm{P} 3)=6.521
\end{aligned}
$$

significant value because the significant is 0.000 $<\alpha=0.05$.

Based on result and discussion above, the first hypothesis is accepted. It can be concluded that this research is in line with the previous studies that conducted by Phillips et.al (2003), Yulianti (2005), Irreza and Yulianti (2012), and Ying Wang et.al (2016) that explain deferred tax expense can be one of the component in detecting earnings management practices and has a significant influence toward earnings management. Furthermore, Philips et.al (2003) explain that manager tend to accomplish the earnings management practice by using their own policy and usually manager 
will follow accounting standard rather than tax law and regulation in creating such policy and manager will looking loopholes in an accounting standard in accordance to increase company's income, so such management behaviour will generate higher temporary book-tax-differences that lead to higher deferred tax expense because management tend to increase company's income without paying attention to applicable tax law and regulation, so it can be concluded that higher deferred tax expense will lead to earnings management practice that done by management in accordance to increase company's income.

The second hypothesis is rejected. This research is not in line with previous studies that conducted by Sumomba and Hutomo (2012) and Negara and Suputra (2017). Sumomba and Hutomo (2012) successfully proves that tax planning that measured using tax retention rates has significant influence toward earnings management practices, in order to respond the changes in tax rates from $28 \%$ to $25 \%$ in accordance with Law of The Republic Indonesia Number 36 of 2008 and the result supports the view that firms attempt to shift income in to the next period when there was an announcement regarding changes in tax rates that are lower than the previous period (Sumomba and Hutomo 2012).

The third hypothesis is rejected. This result is in line with the previous studies that conducted by Djmaluddin et.al (2008) and Sri Wijayanti (2016) that explain there is no influence between deferred tax expense toward company's profitability. Company's profitability contains predictive value elements that can be used by users of financial statements to evaluate past, present and future events (Penman 2001). Based on the research that conducted by Sri Wijayanti (2008) explain that factors that result in deferred tax expense are generally derived from depreciation and amortization. Fiscal depreciation and amortization is greater than commercial, so that the amount of deferred tax expense is not to significant toward company's profitability, because there are other factors that more significant influence towards company's profitability, such as sales, cost and expenses, stock price, total assets, and etc. (Wijayanti, 2016) and this is also in line with the research that conducted by (Djamaluddin et al. 2008).

The forth hypothesis is accepted. Our study is in line with the study conducted by Syanthi et.al (2013) and Giil et.al (2013) that explain earnings management has a significant influence toward company's profitability. Based on research that conducted by Graham et.al (2005) found that $74.1 \%$ of company executives are trying to achieve profit benchmarks or a good profit, because it is able to help them to communicate the prospect of future company growth to shareholders (Graham, Harvey and Rajgopal 2005). Syanthi et.al (2013) found that earnings management practice can increase company's profitability. In the other hand, Gill et.al (2013) indicate that the more intense the practice of earnings management, the greater it's adverse effect on corporate rate of return on assets, because the market realize that management who act with selfish motives will be responded by lowering share prices and corporate market value (Gill et al. 2013).

The fifth hypothesis is accepted. This result is in line the previous studies that conducted by Mangunsong (2002), Sugeng (2011), and Assidi et.al (2016) that found there is a significant influence between tax planning toward company's profitability. According to Pohan (2013), one of the main objective to be achieved by tax planning are to minimize the tax payable and to maximize the profit after tax (Pohan, 2013). Based on the research that conducted by Mangunsong (2002) and Sugeng (2011) explain that tax planning can be done by minimize company's tax payable, so the profit of the company automatically will increase. This activity can be done by utilizing such loopholes in the applicable of income tax law (Mangunsong 2002; Sugeng 2011). In addition can increasing 
company's profitability, based on the research that conducted by Assidi et al. (2016) found that tax planning can improving company's value by doing tax optimization with reducing tax payable of the company (Assidi et al. 2016).

The sixth hypothesis is accepted. It is found that Earnings Management as intervening variable or mediating variable between Deferred Tax Expense toward Company's Profitability (indirect influence) is more effective than the direct influence and based on Sobel Test result, it is found that Earnings Management has a significant influence as intervening variable between Deferred Tax Expense toward Company's Profitability.

Based on the statistical calculation above, it can be seen that deferred tax expense has a negative relationship toward company's profitability, means that if the deferred tax expense increase, then it will be followed by the decreasing of company's profitability. This research is in line and have connection with the first hypothesis and third hypothesis where deferred tax expense has a significant influence with earnings managements but not has significant influence toward company's profitability. Based on the research that conducted by Irreza and Yulianti (2012) found that deferred tax expense is one of component in earnings management practice that management use in accordance to improving company's profitability (Irreza and Yulianti 2012). This statement is supported by statistical calculation above where the coefficient of indirect effect is bigger than the direct effect, so it proving that earnings management as intervening variable strengthen the influence from deferred tax expense toward earnings management.

The seventh hypothesis is rejected. This study finds that Earnings Management as intervening variable is less effective than the direct influence between Tax Planning toward Company's Profitability. In addition, it is found that Earnings Management as intervening variable weakens the influence between Tax Planning toward Company's Profitability. It can be concluded that the direct influence from tax planning toward company's profitability is stronger than the indirect influence (from tax planning to earnings management and then to company's profitability). This result is related with second hypothesis and fifth hypothesis, where in second hypothesis tax planning has no significant influence toward earnings management and in fifth hypothesis tax planning has positive significant influence toward company's profitability and it is supported from this statistical calculation above where the coefficient of direct influence from tax planning directly toward company's profitability is stronger than indirect influence that has negative coefficient and weaken the influence from tax planning toward company's profitability. This is in line with the research that conducted by Mangunsong (2002) and Sugeng (2011) that explain tax planning can be done by minimize company's tax payable, so the profit of the company automatically will increase. This activity can be done by utilizing such loopholes in the applicable of income tax law (Mangunsong 2002, Sugeng 2011).

\section{CONCLUSION}

There is a positive significant influence between deferred tax expenses toward earnings management, it means any increase in deferred tax expense, then the probability of the management doing earnings management will increase too, and vice versa. Another finding is tax planning do not significantly affect earnings management. Deferred tax expense has no influence toward company's profitability, because the amount of deferred tax is derived from the temporary difference which is relatively small when compared to company's profitability, that's why deferred tax expense has no significant influence toward company's profitability. Factors that result in deferred tax 
expense are generally derived from depreciation and amortization. Fiscal depreciation and amortization is greater than commercial, so that the amount of deferred tax expense is not to significant toward company's profitability, because there are other factors that has more significant influence towards company's profitability, such as sales, cost and expenses, stock price, and total assets (Wijayanti 2016).

There is a positive significant influence between earnings management toward company's profitability. There are some activities that done by management that related to earnings management in accordance to increase company's profitability, but despite that, it also can be lowering the company value if the management act with selfish motives. Syanthi et al. (2013) found that earnings management practice can increase company's profitability.

Based on the discussion above, it can be concluded that tax planning has a significant influence toward company's profitability. Tax planning can be done by minimizing the tax payable of the company. By minimizing the tax payable of the company, the income of the company will increase. In addition can increasing company's profitability, based on the research that conducted by Assidi et.al (2016) found that tax planning also can improving company's value by doing tax optimization with reducing tax payable of the company

Deferred tax expense has a significant influence toward company's profitability with earnings management as intervening variable. It can be seen that earnings managements as intervening or mediating variable can strengthen the influence between deferred tax expense toward company's profitability. Additionally, direct influence from tax planning toward company's profitability is more effective than indirect influence from tax planning toward company's profitability through earnings management, because earnings management as intervening or mediating variable weaken the influence tax planning toward company's profitability.

\section{REFERENCES}

Assidi, S., Aliani, K. and Ali, M. O. 2016. 'Tax Optimization and The Firm's Value : Evidence From The Tunisian context', Borsa istanbul Review. Elsevier Ltd, 20, 1-8. doi: 10.1016/j.bir.2016.04.002.

Djamaluddin, S., Handayani, T. W. and Rahmawati. 2008. 'Analisi Perbedaan Antara Laba Akuntansi dan Laba Fiskal Terhadap Persistensi Laba, Akrual, dan Aliran Kas pada Perusahaan Perbankan yang Terdaftar Di Bursa Efek Jakarta', Jurnal Riset Akuntansi Indonesia, 11(1), 55-67.

Ghozali, I. 2011. Aplikasi Analisis Multivariate Dengan Program SPSS 19. Semarang: Universitas Diponegoro.

Gill, A. et al. 2013. 'Earnings Management, Firm Performance, and the Value of Indian Manufacturing Firms', International Research Journal of Finance and Economics, 116, 120-132.

Graham, J. R., Harvey, C. R. and Rajgopal, S. 2005. 'The Economic Implications of Corporate Financial Reporting', Journal of Accounting and Economics, 40, 3-73. doi: 10.1016/j.jacceco.2005.01.002.

Harmana, I. M. D. and Suardana, K. A. 2014. 'Pengaruh Pajak Tangguhan dan Tax to Book Ratio terhadap Kinerja Perusahaan', E-Jurnal Akuntansi Universitas Udayana, 6(3), 468-480. doi: ISSN 2302-8556.

Harnanto. 2013. Perencanaan Pajak. Yogyakarta: BPFE. 
Hidayat, N. 2013. Pemeriksaan Pajak (Menghidari \& Mengahadapi). Jakarta: Gramedia.

Irianto, G. 2003. 'Skandal Korporasi dan Akuntan', Lintasan Ekonomi, 20(2), 104-114.

Irreza and Yulianti. 2012. 'Penggunaan Komponen Pembentuk Pajak Tangguhan Dalam Mendeteksi Manajemen Laba', Jurnal Akuntansi dan Keuangan Indonesia, 9(1), 68-82.

Makar, S. D., Alam, P. and Pearson, M. A. 2000. Earning Management: When Does Juggling The Numbers Become Fraud?, Association of Certified Fraud Examiners. Available at: https://www.acfe.com/article.aspx?id=429496844 (Accessed: 24 March 2018).

Mangunsong, S. 2002. 'Peranan Tax Planning Dalam Mengefisiensikan Pembayaran Pajak Penghasilan', Jurnal IImiah Akuntansi, 2(1), 44-54.

Marques, M., Rodrigues, L. L. and Craig, R. 2011. 'Earnings management induced by tax planning: The case of Portuguese private firms', Journal of International Accounting, Auditing and Taxation, 20(2), 83-96. doi: 10.1016/j.intaccaudtax.2011.06.003.

Negara, A. . G. R. P. and Suputra, I. D. G. . D. 2017. 'Pengaruh Perencanaan Pajak dan Beban Pajak Tangguhan Terhadap Manajemen Laba', E-Journal Akuntansi Universitas Udayana, 20(3), 20452072.

Penman, S. H. 2001. Financial Statement Analysis and Security Valuation. Singapore: Mc. Graw-Hill.

Phillips, J., Pincus, M. and Rego, S. O. 2003. 'Earnings Management: New Evidence Based on Deferred Tax Expense', The Accounting Review, 78(2), 491-521.

Pohan, C. A. 2013. Manajemen Perpajakan. Jakarta: Gramedia.

Resmi, S. 2009. Perpajakan Teori dan Kasus. Jakarta: Salemba Empat.

Scoot, W. R. 2003. Financial Accounting Theory - Third Edition. 3rd edn. New Jersey: Prentice Hall International, Inc.

Scott, W. R. 2012. Financial Accounting Theory. 6th edn. New Jersey: Prentice Hall International, Inc.

Setyawan, B. and Harnovinsah. 2016. 'Pengaruh Beban Pajak Tangguhan, Profitabilitas, dan Perencanaan Pajak Terhadap Manajemen Laba (Studi Empiris Pada Perusahaan Manufaktur Sub Sektor Otomotif Dan Komponen Yang Terdaftar Di Bursa Efek Indonesia Periode 2010-2014)', Keberlanjutan, 1(1), 15-40.

Suandy, E. 2008. Perencanaan Pajak. 4th edn. Jakarta: Salemba Empat.

Sugeng, B. 2011. 'Pengaruh Perencanaan Pajak Terhadap Efisiensi Beban Pajak Penghasilan', Jurnal Riset Akuntansi dan Bisnis, 11(2), 122-139.

Sulistyanto, H. S. 2008. Manajemen Laba: Teori dan Model Empiris. Jakarta: Grasindo.

Sumomba, C. R. and Hutomo, Y. S. 2012. 'Pengaruh Beban Pajak Tangguhan dan Perencanaan Pajak terhadap Manajeman Laba', Kinerja, 16(2), 103-115.

Syanthi, N. T., Sudarma, M. and Saraswati, E. 2013. 'Dampak Manajemen Laba Terhadap Perencanaan Pajak dan Persistensi Laba', Ekuitas: Jurnal Ekonomi dan Keuangan, 17(2), 192-210.

Waluyo. 2014. Perpajakan Indonesia. Jakarta: Salemba Empat.

Wijayanti, H. T. 2006. 'Analisis Pengaruh Perbedaan Antara Laba Akuntansi Dan Laba Fiskal Terhadap Persistensi Laba, Akrual, Dan Arus Kas', Simposium Nasional Akuntansi IX, 9(28).

Wijayanti, S. 2016. 'Pengaruh Beban Pajak Tangguhan Terhadap Persistensi Laba dan Manajemen Laba pada Perusahaan Manufaktur', Jurnal Akuntansi UNESA, 4(2).

Wild, J. J., Subramanyam, K. R. and Halsey, R. F. 2004. Financial Statement Analysis. 18th edn. Boston: Mc. Graw-Hill.

Yulianti. 2005. 'Kemampuan Beban Pajak Tangguhan Dalam Mendeteksi Manajemen Laba', Jurnal Akuntansi dan Keuangan Indonesia, 2(1), 107-129.

Zain, M. 2008. Manajemen Perpajakan. Jakarta: Salemba Empat. 
